\title{
Tax Seminar II on Recent Case Law of the European Court of Human Rights on Taxation and Special Issues on the Taxation of Expatriates
}

\author{
Rabea Lingier, Anna Mehnert, Marija \\ Stankeviciute
}

\section{Introduction}

A tax seminar for students following the LL.M course in Cross-border Taxation of Human Capital was held at the Faculty of Law of Maastricht University on 12 March 2014. The objective of this seminar was to provide the students with additional information and insights on several issues with regard to the taxation of individuals. Dr Marjon Weerepas, associate professor of law at Maastricht University, welcomed the speakers as well as the participating students and gave a brief introduction to the subject of the seminar. The seminar featured two presentations given by Ms Larisa Gerzova, senior research associate in the International Bureau of Fiscal Documentation (IBFD), and Ms Laura Ambagtsheer-Pakarinen, also in the IBFD.

\section{Human Rights and Taxation}

The first presentation was given by Ms Larisa Gerzova, who is an IBFD senior research associate. In her presentation she addressed the case law of the European Court of Human Rights (hereafter ECHR) on taxation. The two central questions were, whether taxpayers indeed need protection and whether taxation can interfere with human rights. Both questions were answered in the affirmative and therefore case law on human rights in taxation arose in the past years. The two main sources to safeguard the law were stated to be domestic law as well as international conventions.

In the 1990 OECD Survey on taxpayers' rights and obligations in OECD countries, it was found that basic taxpayer rights were present in all 
systems. Such rights include, for example, the right to be informed, the right to certainty, the right to privacy et al.

The two main human rights conventions affecting taxpayers were described to be:

(i) European Convention for the Protection of Human Rights and Fundamental Freedoms (ECHR, 1950);

(ii) United Nations International Covenant on Civil and Political Rights (ICCPR, 1966).

Under the UN Covenant on Civil and Political Rights, only a few cases on taxation have arisen. However, the situation is different under the ECHR 1950. The Convention is supervised by the European Court of Human Rights in Strasbourg and there is a direct link with EU law. Although it was written without taxes in mind, it can still be applied to tax cases in certain circumstances. All domestic remedies must be exhausted before the Court can be approached, however, then the judgments finding violations are binding on the states concerned.

The ECHR 1950 contains several provisions that are relevant for taxation, such as Article 6 (right to a fair trial), Article 8 (right to privacy) and Article 10 (freedom of expression).

For example, Article 10 ECHR 1950 provides for the freedom of expression for everyone. In the case Mariapori v. Finland (2010) it was found that the freedom of expression contains the right to defame tax authorities. However, the limits to this freedom have been stated in the case Taffin \& Contribuables Associes v. France (2010). In this case the publishers of a tax bulletin were charged for public defamation of a tax inspector. In an Article, a tax inspector was referred to by name and it was alleged that she has wanted the taxpayer's skin at any price, that she has been completely unaccountable and had committed serious irregularities. The Court then ruled that the freedom of expression includes the right to make statements which might wound, shock or disquiet. However, this freedom also imposes duties and responsibilities. Therefore, there is an obligation of judgment and balance to be exercised by a publisher when considering the accuracy of serious allegations made against a civil servant. Accordingly, it was not allowed to publicly defame a single tax inspector like in a newspaper article as it has been done in Taffin \& Contribuables Associes v. France (2010).

Another interesting provision that was mentioned in the presentation is Article 4 of the 7th Protocol to the ECHR, containing the ne bis in idem principle. This means that nobody should be punished again in criminal proceedings under the jurisdiction of the same State for an offence for which he has already been finally acquitted or convicted in accordance with the law and procedure of that State. In taxation this could become relevant when a taxpayer has failed to submit his tax return in due 
time, which is followed by a penalty and subsequently by a criminal prosecution for tax evasion. It is remarkable that the notions of (i) criminal proceedings, (ii) the "same offense" and (iii) double prosecution can vary extensively and rise uncertainty. Therefore, in Engel and Others $v$. the Netherlands, the three criteria for criminal proceedings were the legal classification of the offense under national law, the very nature of the offense as well as the degree of severity of the penalty that the person concerned risks incurring. These criteria were further modified in subsequent case law.

In Zolotukhin v. Russia (2009) the notion of "the same offense" was harmonized, meaning that Art. 4 prohibits the prosecution or trial of a second "offence" in so far as it arises from identical facts or facts which are substantially the same.

In case there already is a res judicata, there should not be a second prosecution for the same offense. However, it is not precluded under this Article that the taxpayer is punished twice. With this Ms. Gerzova concluded her presentation on human rights in taxation.

\section{Taxation of Expatriates}

The second presentation was given by Ms. Laura AmbagtsheerPakarinen, who is a country specialist for Finland and the Scandinavian countries. The presentation began with the definition of the notion 'expatriates'. It was explained that expatriates are persons who have left their home state and live abroad, however, the permanent residence in another than home country does not mean that all the ties with the home country are severed; generally, the status of expatriate means that there is a change of residence for tax purposes.

Moreover, a distinction between the inward and outward expatriates was made. Inward expatriates are the ones that are coming to reside permanently in a country other than their home country. Countries are trying to attract high qualified (inward) expatriates who would be beneficial to their economies and as a result, their offer special tax reliefs (e.g. various tax-exempt reimbursements and benefits) or special tax regimes (e.g. 'Nokia regime', or flat tax rate regime in Sweden, 30 $\%$ rule in the Netherlands) to the latter. The outward expatriates are the ones that leave their home country. Usually countries do not want to lose highly qualified residents, thus, their might impose exit taxes, extend tax liability on these persons or contrary - give special tax reliefs (e.g. Finish six-month rule: there is no Finish income tax due on the income which source is abroad when working there longer than 6 months). 
Continuing with the presentation, Ms. L. Ambagtsheer-Pakarinen discussed the taxation of the expatriates' income. Firstly, taxation of the passive income (interest, dividends, capital gains, income from immovable property) was dealt with, mainly focusing on the taxation of dividends and interest. Ms. L. Ambagtsheer-Pakarinen explained the cross-border investment situation and draw students' attention to the possible economic and juridical double taxation in case of interest (only juridical) and dividends (both: juridical and economic). It was noted that juridical double taxation can be solved by the double taxation treaties, referring to Art. 10 (1) and (2) or Art. 23 OECD model treaty in respect of dividends and Art. 11 (1) and (2) or Art. 23 in respect of interest. It was also distinguished that the notion of dividends in the OECD model treaty is an open definition which refers to a domestic law of a relevant state whereas the definition of interest is a closed one with no additional references.

Secondly, the issue of taxation of the income from the indirect investments was observed. Ms. L. Ambagtsheer-Pakarinen distinguished the main features of a collective investment vehicle (hereinafter - CIV), which are: (i) widely held (investors from many different countries might invest in a CIV), (ii) diversified assets (investments by CIV are made to different kinds of securities), (iii) subject to investors' protection rules, ( $\mathrm{vi}$ ) subject to double taxation treaties' benefits. The last feature was commented in more detailed way as it is not present in all cases involving CIV. In order for a CIV to be entitled to double taxation treaties' benefits: (i) a CIV has to be a person (whether this criteria is met depends on the legal structure of a CIV), and (ii) be a resident of a receiving state (this criteria is fulfilled if a CIV is subject to 'liable to tax' not 'subject to tax' criteria), and (iii) be a beneficial owner of the interest/dividends it receives (this criteria should not be understood in a narrow/technical sense, rather it should be examined whether a CIV acts on itself, e.g. has a wide group of investors, managers who exercise their authority to manage assets on behalf of the holders of interest in a CIV). In addition to all the mentioned, it was emphasized that even if a CIV is not entitled to double taxation treaties' benefits, the underlying investors still should be entitled to the mentioned benefits.

Thirdly, Ms. L. Ambagtsheer-Pakarinen examined the employmentrelated income - pensions. As a general rule, pensions are exclusively taxed in a state of residence (OECD model treaty, Art. 18), however, issues might arise when a change of residence state of pensioners is involved. The issue is mainly related to the variation of taxation of social security contributions among the states. Some states allow the deduction of social security contributions with a respect that the pension 
will be taxable income when received, other, however, do not allow the deduction of social security contributions and thus, do not subject pensions to taxation when received. As a result, the clash between different systems appears when a pensioner moves. There are two possibilities: (i) double non-taxation: a person was allowed to deduct his social security contributions and after moving and starting to receive his pension, the latter is not subject to taxation; (ii) double taxation: a person was not allowed to deduct his social security contributions and after moving and starting to receive his pension, the latter is subject to taxation. The practical solution of the mentioned issue was demonstrated with the example of Denmark. Danish pensioners are granted a deduction of social security contributions from their taxable income as the pensions are taxed when they are received. However, most of the Danish pensioners used to move to Spain or France after they reach the age of retirement which meant no taxing right for Denmark. Denmark responded to this issue by terminating double taxation treaties with Spain and France from 2009 and all the amending protocols concluded after that now include specific rules stating that Denmark has a right to tax pensions even in a case where a change of resident state is involved.

Lastly, the taxation of gifts and inheritance was explored. It was distinguished by Ms. L. Ambagtsheer-Pakarinen that there are a lot of differences between states in a case of taxation of gifts and inheritance: some countries tax, some not, the base of the taxes is different, gifts/inheritance might be subject to specific taxes or fall under the scope of personal income tax. All these mismatches create a high risk of double taxation, however double taxation treaties in a field of estate, inheritance and gifts taxation still are not popular (e.g. in the EU, only 33 treaties have been concluded out of possible 351). After mentioning that Ms. L. Ambagtsheer-Pakarinen overviewed the OECD estate, inheritance and gift tax model convention and concluded that in respect of the EU, possible double taxation of inheritance is hindering a free movement of people but harmonization on this level is not feasible any time soon. 